$\xi=-1$

\title{
Comparison of Amendments to the Value Added Tax Law between Indonesia and Malaysia to Regulate Murabaha Transactions
}

\author{
Thesa Adi Purwanto* \\ Tax Administration Laboratory, Vocational Education Program, Universitas Indonesia \\ *Corresponding author E-mail: thesa@vokasi.ui.ac.id
}

\begin{abstract}
Islamic banking in their activity base on Islamic principles that is agreement regulation on Islamic Law between Bank and others to saving and or financing an activity or business which suit Islamic role. There are several forms of financing, such as financing on sharing profit principle (mudharabah), financing on participation principle (musyarakah), transaction goods principle which get profit (murabaha), financing capital goods on rent principle without choice (ijarah), or with transfer authority over the rent goods from bank to others (ijarah wa iqtina). Furthermore, development of Islamic banking either in Indonesia or Malaysia must be followed with new law and regulation from their government, especially for rules on taxation over transaction on Islamic banking. This is critical because there are different interpretation and argumentation between practitioners of Islamic banking and the government about the subject of Value Added Tax on murabaha transaction. This research used a qualitative approach, using literature study, which emphasizes books as an object and field study with collecting data by interviewing and also using secondary data. As a result, both Indonesia and Malaysia has undergone essential steps to provide Islamic finance with appropriate banking and tax regulations that have succeeded in supporting the Islamic financial system.
\end{abstract}

Keywords: Islamic banking; Murabaha; Indonesia; Malaysia; Value added tax.

\section{Introduction}

The development of sharia banking is marked by the emergence of Bank Muamalat Indonesia (BMI) on May 1, 1992, which was then supported by the enactment of Law No.21 of 2008 on Sharia Banking more rapidly (1). The rapid development is marked by the enactment Act No.10 of 1998 concerning an amendment to Act No.7 of 1992 about Banking. In Law No.10 of 1998 regulated in detail the legal basis and the types of business that can be operated and implemented by Islamic banks. Law No.10 Year 1998 also provides direction for conventional banks to open sharia branch or even convert themselves totally to sharia (2). The rapid development of sharia banking was greeted enthusiastically by the banking community. Some banks began to provide training in sharia banking for their staff. Some of these banks want to explore to open a division or sharia branch within the institution. Some even plan to convert themselves entirely into sharia banks. The peak when in 2003 came the fatwa of Majelis Ulama Indonesia (MUI) about the usury of usury, conventional banks began to compete to open sharia units to catch this brighter business. In subsequent developments, the sharia banking industry has shown unexpected results. The results achieved by practitioners of sharia banks in raising public funds is quite good. Total Third Party Funds (DPK) collected in 2012 only about Rp150,44 trillion, now jumped dramatically to almost Rp285,2 trillion in 2016 (3). The Government of Indonesia has regulated on sharia banking since Act No.7 of 1992 concerning Banking as amended by Act No.10 of 1998 (from now on referred to as the Banking Law). According to Banking Law, sharia bank is a commercial bank conducting business activities based on sharia principles, including sharia business unit. The sharia principles referred to herein refer to Article 1 point 13 of the Banking Act. The evolving and conducive development of sharia banking began in Law No.7 of 1992 with the introduction of a profit-sharing system and continued with the recognition of the existence of sharia bank entities in Act No.10 of 1998. The existence of a sharia bank in Indonesia must be in the form of a limited liability company, a cooperative or a regional company. Like other commercial banks, sharia banks can only be established and conduct their business activities after obtaining a license from the board of directors of Bank Indonesia. Following the enactment of Law No.23 of 1999 on Bank Indonesia, such permission is granted by the Board of Governors of Bank Indonesia (4). Although the existence of sharia banking has been accommodated by Law No.10 of 1998 and Act No.23 of 1999, the civil aspects and related taxation provisions in sharia banking transactions and engagements have not been adequate. To regulate the existence of sharia banking, the Government of Indonesia has issued Law No. 21 of 2008 concerning Sharia Banking. In the regulation, the business activities of sharia banks include, among others, firstly collecting funds from the public in the form of savings and investments such as demand deposits based on wadi'ah principles; savings based on wadi'ah and/or mudaraba principles; time deposits based on the principle of mudaraba, the second is to channel funds through the principle of sale and purchase based on the contract, among others murabaha; istishna; regards; through the principle of profit sharing based on contracts, among others, mudaraba; musharaka; through lease principle based on contracts, among others ijara; ijarah muntahiya bittamlik; through borrowing 
and borrowing principles based on qardh contract, the third is to provide banking services based on contracts, among others, wakalah; hawalah; kafalah; rahn, the fourth carried out other activities commonly undertaken by the Bank to the extent approved by Bank Indonesia and obtained a fatwa of the National Sharia Council. Based on the law we can see that both sharia banks and conventional banks have the same business activities, namely to collect funds from the community and make the distribution of funds to the community. The main difference between the activities of banks based on sharia principles and conventional banks lies in the system of rewards or services of funds (5). Although in Law No. 21 of 2008 mentioned about principles and contracts used by Islamic banks in carrying out its activities, but in the regulation does not explain how the principle mechanism and contract are executed. This can create obstacles to implementing these principles and covenants. In the implementation of the provision of taxation on sharia banking, there are often problems arising from the fundamental factors underlying the establishment of Islamic banking and the operational activities of sharia banking than conventional banking. The problem arises from the foundation of thinking underlying the provisions of taxation based on the economic system that is based not on Islamic sharia, a thing that is very different from sharia banking that bases itself on an economy that is imbued by Islamic shari'a (6). Bank Indonesia Deputy Governor Perry Warjiyo, at the opening of the Shariah Economic Festival (FESyar) of Eastern Indonesia (KES), said Indonesia's sharia economy is far behind compared to other countries, even in some European countries. Further, if the approach taken for the imposition of tax on sharia transactions using the applicable provisions, growth, and development of Islamic banks may be hampered Some research results also conclude that the taxation laws in Indonesia are considered unfair to the sharia banking industry. Some transactions in sharia banking are subject to Value Added Tax, whereas in conventional banks it is not. In comparison, Bank Indonesia conducts a review of special taxation provisions for sharia financial transactions in Malaysia, the UK and Australia. As an early stage of developing sharia financial institutions, the Government of Malaysia is very accommodating to the provisions of taxation. Malaysia has made improvements to its tax laws including the Income Tax Law, the Stamp Duty Act, and the Acquisition of Property Acquisition Take Over. All improvements to the law were made to avoid discriminatory tax provisions between conventional and sharia financial instruments. Through the amendment of the Act, Malaysia wishes to emphasize that in essence the implementation of sharia financial transactions that require the occurrence of more than one transfer of ownership in order to comply with sharia principles in the end together with conventional bank products. Thus, it may be exempt from tax collection except on the parent transaction. The British government is also doing the same thing in terms of housing finance with murabaha or musyarakah mutanaqishah (joint ownership with a declining portion of the bank). Islamic Islamic mortgage transactions in the UK since 2003 have been charged only one tax. In fact, Muslims are a minority. Similarly, Australia, The State Taxation Act 2004 provides a number of exceptions in the application of taxation of sharia financial transactions in Victoria Australia (7).

\section{Literature Review}

The activities of banks after collecting funds from the wider community in the form of various deposits are channeling the funds back to the people who need them (intermediary). In general, the channeling of funds in banks that use conventional system is the provision of credit, whereas in the Islamic banking channeling of funds is done by the contract of sale and purchase and profit sharing (8). Buying and selling is an exchange transaction between 'ayn in the form of goods with dayn in the form of money. This transaction is commonly referred to as a sale and purchase transaction, in this transaction the sales gain is included in the selling price, so the seller does not need to notify the profit level to the buyer. As for the rukun of buying and selling (Murabaha) is:

a. Seller (Ba'i)

b. Buyer (Musytari ')

c. Goods Object (Mabi ')

d. Price (Tsaman)

e. Ijab Kabul (Sighat).

If the contract (agreement or agreement) has taken place, means all the rukun and conditions are met, then the consequences; the seller moves the goods to the buyer, and the buyer moves his / her property to the seller, according to the price agreed by both parties. The buying and selling take place with the consent and exclusion, except for small items, not necessarily with the consent and mercy, by merely giving each other by the prevailing customs. According to Sayyid Sabic in the book of Fikih Sunnah, the consent is an expression that comes out first and to one of two parties, and the second is kabul, and there is no difference between the one who mengijab the seller and the one who grabs the buyer or vice versa, where the mengijabkan is the buyer and granted the seller (9). According to Sayyid Sabic required in the consent and kabul which are both called shighat akad, as follows (9):

a. Each one corresponds to one place without any destructive separation.

b. There is a consensus with kabul on goods which are mutually in the form of goods sold and the price of goods. If both parties do not agree then, the sale and purchase (akad) declared invalid.

c. The phrase must show the past (madhi) as the seller's words "I have bought" and the words of the buyer "I have received," or the present (mudhari ') if it is cold at that time. Like "I am now selling, and I am buying now." If the desired future or there is a word that shows the future, then it is a promise to berakad. The promise of unlawful as a legitimate contract, therefore, becomes invalid legally.

The forms of buying and selling contracts that have been discussed by scholars in fiqh muamalah Islamiah spelled out very much; the number can reach dozens. Three types of buying and selling have been developed as the main staple in working capital financing and investment in sharia banking, namely murabaha, salam and istishna (2). Murabaha is the sale and purchase of goods at the original price with an additional profit agreed upon, so in murabaha, the seller must tell the price of the purchased product and determine a profit level also. Murabaha is the principle of buying and selling (ba'i) where the selling price consists of the cost of goods plus the value of profit (ribhun) agreed. On murabaha, the delivery of goods is done during the transaction, while the payment can be made in cash, robust or installments (installment). Murabaha arises because the bank does not have the goods desired by the buyer, so the bank must make purchases transactions on the desired goods to other parties called suppliers. Thus, the bank acts as a seller on one side, and on the other hand, acts as a buyer. Then the bank will resell it, to the buyer with the adjusted price, i.e., the purchase price plus the agreed margin (ribhun). As for the conditions of sale and purchase using murabaha according to Wahbah al-Zuhaili, as quoted by Jaih Mubarok are $(10-12)(8)$ :

a. Seller and buyer know the purchase price of the object to be on sale;

b. Both parties know the amount of profit to be provided by the buyer to the seller;

c. The items to be sold have comparisons so that they can be measured by scales, doses, or others to know the price;

d. Objects sold are excluded objects forbidden to trade; and

e. The first purchase agreement (before the item is resold) including the transaction is correct or saheeh.

Murabaha financing in sharia banking can be compared with the provision of credit in conventional banks, as in the table the following: 
Table 1: Comparison of Murabaha Transactions with Credit Transactions Murabaha on Sharia Bank $\quad$ Credit on Conventional Bank

\begin{tabular}{|c|c|}
\hline $\begin{array}{c}\text { Selling in the form of goods to } \\
\text { customers }\end{array}$ & $\begin{array}{c}\text { Giving credit in the form of money } \\
\text { to customers }\end{array}$ \\
\hline $\begin{array}{c}\text { Customer debt at the selling price } \\
\text { (fixed) during the murabaha period }\end{array}$ & $\begin{array}{c}\text { Customer debt at the loan plus } \\
\text { interest changing (non-fixed) }\end{array}$ \\
\hline Supplier analysis & No supplier analysis \\
\hline $\begin{array}{c}\text { Margin based on the value added / } \\
\text { business added }\end{array}$ & $\begin{array}{c}\text { Interest-based on prevailing market } \\
\text { rate }\end{array}$ \\
\hline
\end{tabular}

To apply some fiqh muamalah concepts that are believed to be the source of sharia banking and economic system in the banking system, Bank Indonesia needs the help of ulama in this case the Indonesian Ulema Council (MUI) to issue fatwas concerning economy and sharia banking. To respond to the growing interes of the community to sharia lawyers, the MUI established the National Sharia Council (DSN) in Jakarta and the Sharia Supervisory Board (DPS) in each bank that organizes the sharia system. One of the fatwa of the National Sharia Board of MUI concerning the implementation of murabaha in sharia banking is the fatwa of the National Sharia Council MUI Number 4 / DSN-MUI / IV / 2000 concerning Murabaha and Number 13 / DSN-MUI / IX / 2000 concerning Advances in Murabaha. In the fatwa, The National Sharia Board of MUI concerning murabaha is:

a. In buying and selling murabaha known as advance payment, and

b. There are general murabaha provisions, provisions for customers, guarantees, debts in murabaha, delays in payments, and bankruptcy.

General murabaha provisions outlined in the fatwa of the National Sharia Board of MUI are:

a. Banks and customers commit a murabaha contract free of usury;

b. Islamic sharia does not forbid goods traded;

c. The Bank finances part or all of the purchase price of that good has been agreed upon its qualifications;

d. The Bank purchases the required goods on behalf of the bank itself, and this purchase is legitimate and free of usury;

e. The Bank shall disclose all matters relating to the purchase, for example, if the purchase is made in debt;

f. The Bank sells the goods to the customer (buyer) at the selling price of the purchase price plus the profit, and the bank tells honestly about the cost of goods and the required cost;

$\mathrm{g}$. The Customer pays the agreed price of the Goods for a specified period;

h. The bank may enter into exclusive agreements with its customers to prevent any misuse or damage of the contract;

i. If the bank wishes to represent the customer to purchase the goods, the sale and purchase contract of murabaha shall be made after the goods in principle become the property of the bank.

Murabaha provisions for customers as regulated in the fatwa of the National Sharia Board of MUI are:

a. The Customer shall apply and purchase agreement of a goods or asset to the bank;

b. Upon receipt of the application, the bank buys it first assets he legally ordered with merchants;

c. The Bank offers such assets to customers and customers must buy it by the agreement it has agreed upon because the contract is legally binding; then both parties make a sale and purchase contract;

d. Banks are allowed to ask customers to make a down payment when signing an initial booking agreement;

e. If the customer refuses to purchase the item, the real cost of the bank must be paid from the down payment;

f. If the advance value is less than the loss incurred by the bank, the bank may request back the remaining loss to the customer;

g. If advances using the urbun contract as an alternative to advance payment then:

i. If the customer decides to purchase the item, the customer pays the remaining price; and ii. If the customer fails to purchase, the money becomes the property of the bank, at a maximum of the loss incurred by the bank due to such cancellation; and if the down payment is insufficient, the customer is required to pay off the shortfall.

The guarantee is not a harmonious or absolute requirement fulfilled in murabaha, the guarantee is allowed for severe customers to order; and the bank may ask the customer to provide a guaranteed (rahn) that can be held. In operational engineering, the ordered goods can be one of the acceptable warranties for debt repayment. The provision of debt in murabaha, in principle, the settlement of customer debt in murabaha transaction has nothing to do with other transactions conducted by customers with third parties over the goods. If the customer resells the item with any profit or loss, the customer remains obliged to settle the debt to the bank:

a. If the customer sells the goods before the term of the installment ends, the customer is not obligated to pay off all installments immediately; and

b. If the sale of the goods is causing the loss, the customer will still settle his debt according to the initial agreement, and shall not delay the payment of the installment or require the loss to be considered.

Conditions on delays in customer payments in murabaha are:

a. For customers who have sufficient economic ability are not justified in delaying the settlement of its debt; and

b. If the customer delays fixed payments, or if one of the parties does not fulfill his obligations, the settlement of this is done through a legal procedure to the Sharia Arbitration Board after no agreement is reached through the deliberation.

While the provisions regarding bankruptcy in murabaha are if the customer has been declared bankrupt and failed to settle the debt. This happens because the customer is completely incapable of being economically and not being negligent while the customer is capable, the bank must postpone the debt until the customer can repay it, or based on the agreement.

\section{Methodology}

\subsection{Research Approach}

In this research, the approach used is the qualitative approach, where researchers are directly involved with the object of his research through in-depth interviews with the parties concerned. Cresswell defines a qualitative study as: "a process of understanding a social or human problem, based on building a complex, holistic picture, formed with words, reporting detailed views of informants and conducted in a natural setting" (13). Regarding the qualitative approach, Neuman says: "data for qualitative researchers sometimes is in the form of numbers; more often it includes written or spoken words, actions, sounds, symbols, physical objects, or visual images (e.g., maps, photographs, videos.)" (14).

\subsection{Type of Research}

The type of research used is descriptive. Descriptive research can be interpreted with problem-solving procedures that are investigated by describing or describing the state of the subject or object of research at the present moment based on facts that appear or as it is (15).

\subsection{Data Collection Techniques}

Data collection techniques aim to collect data or information that can explain the problem of objective research. This study is conducted by collecting and studying the data and information obtained from the provisions of banking regulations in both bankings in general and sharia banking, and the provisions of taxation, especially Value Added Tax. Other supporting data are taxation and banking books, tax and banking journals, and other literature 
sources. Field studies are an important technique in this research In this technique, information is obtained either verbally through in-depth interviews as well as written information from the resource persons. The interview is a method of collecting data by asking directly (communicating directly) with the respondent. In the interview, there is a process of interaction between the interviewer with the respondent (16). Researchers conducted interviews with several sources, namely sharia banking practitioners, sharia banking policy formers and tax policy formulator.

\section{Results and Findings}

According to the results of the study on the aspects of taxation on Islamic banks and interviews with one member of the Implementation Team of the Study of the Directorate of Islamic Banking of Bank Indonesia, it is known that the uniqueness of the products of sharia banking services that often use the term that has not been widely known also result in differences in interpretation. An extra process of understanding is needed to explain how the implementation of the provisions of the Laws and Regulations on taxation on products and services of sharia banking. For example, murabaha financing products that are ideally made at least twice the process of transferring ownership of goods ie from suppliers to Islamic banks and from sharia banks to customers, where when applied to the provisions of Value Added Tax as applied to the trading company there will be tax imposition on any process of delivery of taxable goods. To overcome the problems of taxation that have not accommodated the specificity of sharia banking products and services, adjustment of the process of sharia bank product transactions, for example by executing murabaha through the scheme of delegation of authority (power / wakalah) to buy to customers as well as adjustment of other transactions that can lead to not the implementation of sharia provisions nicely. Efforts by banks to anticipate transaction schemes in order to avoid tax treatment that can increase the tax burden and competitiveness of products and services offered, in addition to assessed not in line with the basic norm that is the compliance to all rules of applicable legal norms, can also impact on the increase the risk of a decline in reputation due to doubt on the fulfillment of sharia in all financial transactions conducted by Islamic banks. According to the study of tax aspects of sharia banks issued by the Directorate of Sharia Banking of Bank Indonesia, the tax treatment related to the provisions of the Value Added Tax Regulation on murabaha transactions with syaria banks can be seen from point of view that Murabaha transaction is a banking activity that is not subject to Value Added Tax if the Directorate General of Taxes fully receives the description of banking activities in Act Number 7 of 1992 concerning Banking as amended by Act Number 10 of 1998 which affirms murabaha activity is part of banking services (17). From the opinions and arguments that have been given by some practitioners and observers of sharia banking in Indonesia, it is clear that sharia banking practitioners and observers assume that the murabaha transactions in Islamic banking are not subject to Value Added Tax, because murabaha transactions include one type of banking services are exempted from the imposition of Value Added Tax as set forth in Article 4A number (3) of the Value Added Tax Act and Article 5 and Article 8 of Government Regulation No. $144 / 2000$. This argument is based on murabaha in syariah banking is one of intermediation function which is one of fund distribution to the public. This is by Law Number 7 the Year 1992 concerning Banking as amended by Law Number 10 of 1998, which among others regulates:

a. Article 1 point 13 states that the Sharia Principle is a rule of agreement based on Islamic law between banks and other parties for the storage of funds and / or financing of business activities, or other activities stated in accordance with sharia, such as financing based on the principle of sale and purchase of goods by making a profit (murabaha). b. Article 6 letter $\mathrm{m}$ states that business of commercial banks, among others, is to provide financing and conduct activities based on Sharia Principles, by the provisions stipulated by Bank Indonesia.

Sharia banking transaction activity is not financial sector based banking as in conventional banking system, whereas transactions in syariah banking apply real sector based banking. Real sector transactions involve real assets and financial assets that are the implementation of Theory of Change. According to fiqh muamalah in Exchange Theory that the object of exchange is a real asset ('Ayn) in the form of goods and services and financial assets (Dayn) in the form of money and securities. Exchange transactions whose delivery is made in the future are not allowed, as this is the same as exchanging something that is unclear in the future. There will be potential losses of either party in the future. While the exchange transaction between financial assets (Dayn) in the form of money with financial assets (Dayn) which is also in the form of money is not allowed. The exchange between money and money we know the term credit/financing. Because it is not allowed by sharia, the provision of credit/financing in Islamic banks is made with the principle of buying and selling, with the principle of the lease, the principle of profit sharing and with a complementary contract. When associated with the Theory of Exchange then the transaction murabaha is an exchange between real assets ('Ayn) in the form of goods with financial assets (Dayn) in the form of money. The exchange of goods with money we are familiar with the terms of buying and selling. Although murabaha transactions are transactions (exchanges between real assets ('Ayn) in the form of goods with financial assets (Dayn), i.e., in the form of money), in essence, the transaction is a financing transaction performed by sharia banks. Murabaha transactions in Islamic banks are also included in service transactions since they can be included in the primary service offering categories supported by minor goods and services. Offering a company to a market usually includes several services. This service component may be a small part of a significant part of the overall offer. In fact, an offer can vary from two extreme poles, i.e., purely goods on one side and real services on the other. Based on these criteria, the offering of a company can be divided into five categories (18):

a. Pure physical product. Offer solely consists only of physical products, such as bath soap, toothpaste, or laundry soap, without any services or services accompanying the product.

b. Physical products with support services. In this category, the offer consists of a physical product accompanied by one or more services to increase the attractiveness of the customer. For example, car manufacturers have to offer much more than just cars, which can include delivery services, repairs, installation of spare parts, and so forth.

c. Hybrid. Offers consist of goods and services of the same size.

d. Significant services supported by minor goods and services. The bid consists of a main service together with additional services (complimentary) and supporting goods. For example, airplane passengers who buy transportation services. During the journey to their destination, there are several elements of physical products involved, such as food and drinks, magazines or newspapers provided, and others. Such services require goods of an intensive capital (in this case the aircraft) for their realization, but the primary offering services.

e. Pure service. Offer almost entirely in the form of services. For example physiotherapy, psychological consultation, massage, and others.

Murabaha transaction offered by sharia bank is a financing service. In this transaction, the existence of Goods Object (Mabi ') is an absolute requirement for financing to be realized. While the ownership of the Customer for the Goods Object (Mabi ') is the goal to be achieved on the utilization of this financing service. When viewed from the standpoint of consumers, services can be classified into two main groups, namely (19):

a. For Consumer (facilitating services), i.e., services that are used as a means or media to achieve specific goals. 
i. Transportation, for example, airplanes, buses, trucks, and trains.

ii. Communication, such as TV, radio, and telephone.

iii. Financially, such as insurance and banks.

iv. Accommodation, such as restaurants and hotels.

v. Recreation, e.g., tourist park.

b. To consumer (human services), ie services addressed to consumers.

i. People processing, differentiated into:

a. Voluntary, such as employment centers and X-ray facilities (Rontgen).

b. Involuntary, such as clinical diagnosis and juvenile court.

ii. People changing, consisting of:

a. Voluntary, such as universities (colleges) and places of worship.

b. Involuntary, such as hospitals and prisons.

Characteristics of service according to the chief Gronross is intangible and simultaneity (20). Due to the characteristics of services that intangible and simultaneity cause the emergence of following characteristics, namely perishability, and heterogeneity, as described by Steven Desmet et al. (21):

"Both intangibility and simultaneity imply further characteristic:

- Intangibility implies perishability. Services cannot be kept in stock like goods. It is not possible to produce services at one moment in time, store them, and take them from shelf to sell when appropriate, as it with goods.

- Simultaneity implies heterogeneity. The fact that both providers and customers need to interact at a certain point within the service delivery process opens up possibilities for variation. Customers, service providers, the surroundings and even the moment of interaction are all sources of variation; consequently, service delivery processes will tend to be characterized by increased heterogeneity. "

If it is linked to murabaha transaction in the syariah bank, it can be concluded that murabaha transaction is a service transaction, because the transaction is perishability and heterogeneity. Murabaha transactions in Islamic banks cannot be stored as inventory that can be enjoyed on other occasions; the transaction will also be felt differently between one customer with another customer. Concerning murabaha transactions in Islamic banks, Mervyn K. Lewis and Latifa M. Algaoud argue (22):

"In the days before conventional banks began investing funds in loans to developing countries and on commercial real estate developments, they followed some rules of 'sound banking.' One of these, the basis of the 'real bills doctrine,' was the idea that banks should confine their lending to 'self-liquidating' papers. An example is the discounting of trade bills. Taking in deposits and lending against trade bills would be considered to be 'self-liquidating' because deposits can be repaid from the receipts of the maturing loans. This is not a lot different from a murabaha transaction, except that the bank is in this instance of buying and selling a commodity rather than a debt security, and must carry the different risks inherent in the commodity market. "

Since the beginning of the existence of conventional banks have been known for the financing of real-sale, known as real bills doctrine. The Bank takes the margin from the discount on the sale and purchase transactions financed from customer deposits. Then the customer's savings will be returned from the repayment of the matured financing. Such financing does not vary much with murabaha transactions, except in murabaha transactions the bank must buy and resell the commodity and must bear the different risks caused by the market situation of the commodity. According to the current theory of Financial Intermediation, bank analysis focuses not only on a role in mediating between lenders and borrowers, but instead focuses on the role of banks as delegated monitors, as Mervyn K. Lewis and Latifa M. Algaoud write (22):

"Traditional analyses of banks are concerned with the importance of leverage and borrowers, and by their respective capacities. We have a central feature of the modern literature-the role of banks as delegated monitors. By engaging in indirect finance, the saver, as depositor, does not have to monitor the financial condition and performance of the borrower, this task is delegated to the intermediary. For most savers, this is not a time-honored, inclination, money, or skill to evaluate the performance insiders. Accordingly, they pass the agency problem and costs on the intermediary, which act as their agent. Outsiders are better off (regarding costs saved) by delegating the tasks of monitoring the insiders to them financial intermediaries as banks with human and reputational capital invested in the monitoring process. "

Based on the theory of Financial Intermediation, murabaha transactions in Islamic banks include types of services in the banking sector, because these activities are conducted to channel bank funds from lenders to borrowers in the context of financial intermediation. Banking services in the framework of financial intermediation including services exempted from the imposition of Tax Value Added, especially when using the Indirect Subtraction Method or known as the credit method. The following according to Organization for Economic Co-operation and Development (OECD):

"Conventional wisdom holds that financial services shall not be included in the VAT basis of the pure interest rate, the premium, or the rate of return which should not be taxed." (23).

To know the problem of the imposition of Value Added Tax, OECD declare must separate three components in a banking transaction, that is the principal, the pure rate of time discount or real rate of interest, and the intermediation charge.

"To understand the VAT problem, it is useful to distinguish three components of banking transactions: the principal, the true rate of the time discount or real rate of interest, and the intermediation charge. The principal should not be taxed since it is merely a transfer of funds and does not represent consumption. Also, the pure rate of interest should not be taxed since it is the depositor's reward for postponing consumption. The intermediation charge, presumably, should be taxed. It represents the value of services rendered to depositors and borrowers, consumers as well as producers. The problem, however, is that the intermediation of charge is embedded in interest rates." (23).

If it is linked to murabaha transaction in the syariah bank, it can be concluded that margin taken by the bank in murabaha transaction is a combination between the intermediation charge and rate of time discount, so it can not be used as the basis of calculation of Value Added Tax. While Tait classified financial services as a difficult-to-tax goods and services. Tait wrote:

"Because the price paid by the user of the services (interest rate, policy premium, and so on) embodies both the price of the services and other considerations, it can not be used as a basis for a VAT. Thus, the indirect calculation used in the invoice-method VAT, whereby tax is computed on the price of the good or service and tax on inputs is subtracted, cannot be used. " (24).

Since the fees paid by the service user (interest, premium, and so on) are a combination of fees for services and other costs, these costs cannot be used as a basis for VAT calculation, so the indirect calculations used in the invoice method, where the tax is calculated from the price of the goods or services and input tax to be reduced, cannot be used.

Malaysian tax legislators introduced different amendments to address the tax treatment of Islamic financial instruments. The amended tax laws are the Income Tax Act 1967 (ITA), the Stamp Act 1949 (SDA) and the Real Property Gains Tax (RPGT) Act 1976 (25). Income Tax Act 1967 has made specific provisions on Islamic transactions. Section 2(8) was included as a new provision to address the tax treatment of Islamic income and income generated from Islamic financial instruments. Section 2(8) of the ITA states that "Subject to subsection (7), any reference in this Act to the disposal of an asset or a lease shall exclude any disposal of an asset or lease by or to a person pursuant to a scheme of financing approved by the Central Bank, the Securities Commission, the Labuan Financial Services Authority or the Malaysia Co-operative Societies Commission, as a scheme which is in accordance with the principles of Syariah where such disposal is strictly required 
for complying with those principles but which will not be required in any other schemes of financing" This implies that the Act allowed Islamic financing to continue without any tax issues relating to asset transfer or lease (26). Apart from the Income Tax Act, stamp duty exemption order has been issued to ensure that Islamic financing transactions are not adversely taxed as compared with the conventional financing transactions. Stamp duties are imposed on a large number of documents and contracts including a charge or a mortgage, and conveyance, assignment or transfer. Stamp duties are imposed on an ad valorem basis although specific stamp duties are levied on certain documents. Item 32 of the First Schedule SDA lists the ad valorem rates levied on a conveyance, assignment, or sale; Item 27 , on a charge or mortgage. The tax base for a conveyance, assignment or sale is the value of the consideration or the market value of the property concerned; for a charge or mortgage, the amount of the financing or loan. The ad valorem rates for a charge or mortgage are lower (25). Stamp Duty (Exemption) (No. 2) Order 2004 states that all instruments executed between a customer and a financier under an Asset Sale Agreement or an Asset Lease Agreement made under the principles of the Shariah to renew any Islamic revolving financing facility. In a nutshell, for Islamic finance transactions, due to the underlying asset within each transaction, tax neutrality, as well as the tax treatment of profits, need to be resolved as tax issues tend to arise in most countries. Tax neutrality is a form of tax incentives whereby a relief is given to the tax charges that was supposed to be imposed on the Islamic financial transactions. In fact, Malaysia was among the first country to accord tax neutrality to Islamic finance instruments and transactions to reduce the cost of transferring assets in Islamic finance. This measure has promoted a level playing field between conventional and Islamic financial products. Section 2(8) of the Act necessarily allows the underlying sale of assets or leases to be ignored for tax purposes so that any additional tax as a result of the underlying transaction would not arise. It enables Islamic financing to continue without any tax issue relating to asset transfer or lease, as such placing the Islamic financing on the same footing as conventional financing. Approval for the Islamic financing has to be granted by the relevant authorities namely Bank Negara Malaysia, Securities Commission and the Labuan Financial Services Authority. There is always a need for tax neutrality so that Islamic finance is put on equal tax treatment compared to conventional finance. Otherwise, Islamic finance will not be attractive or competitive compared to conventional finance (26).

\section{Conclusion}

Based on the results of the analysis using several existing theories can be concluded that murabaha transactions include types of services in the field of banking because the activity is done to channel bank funds from lenders to borrowers in the context of financial intermediation. Banking services in the framework of financial intermediation including services exempted from the imposition of Value Added Tax.

Development of Islamic banking either in Indonesia or Malaysia must be followed with new law and regulation from their government, especially for rules on taxation over transaction on Islamic banking. This is critical because there are different interpretation and argumentation between practitioners of Islamic banking and the government about the subject of Value Added Tax on murabaha transaction. Both Indonesia and Malaysia has undergone essential steps to provide Islamic finance with appropriate banking and tax regulations. These regulations have succeeded in presenting the Islamic financial system as a strong competitor to the conventional financial system.

\section{References}

[1] Karnaen Anwar Perwataatmadja MSA. Apa dan bagaimana bank Islam: Islamic Development Bank, International. Dana Bhakti Wakaf; 1992. 122 p.

[2] Antonio MS. Bank syariah: dari teori ke praktik. Gema Insani; 2001. $255 \mathrm{p}$.

[3] Departemen Perbankan Syariah OJK. Laporan Perkembangan Keuangan Syariah Tahun 2016. Jakarta; 2016.

[4] Sutan Remy Sjahdeini. PERBANKAN SYARIAH. Jakarta: Kencana; 2014. 498 p.

[5] Prof. Dr. Bustari Muktar. Bank dan lembaga Keuangan Lain Prenada Media; 2016. 330 p.

[6] Chandra Budi. Perlakuan Pajak Ganda atas Usaha Syariah | Direktorat Jenderal Pajak. 2011.

[7] Departemen Perizinan dan Informasi Perbankan OJK. Statistik Perbankan Syariah Agustus 2017. Jakarta; 2017.

[8] Mubarok J. Dinamika fatwa produk keuangan syariah. IJTIHAD J Wacana Huk Islam dan Kemanus. 2013 Jun;13(1):1-14.

[9] Al-Faifi S. Ringkasan Fikih Sunnah Sayyid Sabiq. 2014. 984 p.

[10] Alamer ARA, Salamon HB, Qureshi MI, Rasli AM. CSR's measuring corporate social responsibility practice in Islamic banking: A review. Int J Econ Financ Issues. 2015;5.

[11] Rajeh A, Alamer A, Salamon H Bin, Qureshi MI, Rasli AM. International Journal of Economics and Financial Issues A New Business Process and Outcome Oriented Corporate Social Responsibility Index for Islamic Banking. Int J Econ Financ Issues. 2015;

[12] Ali Alamer AR, Salamon HB, Qureshi MI, Rasli AM. How do we measure corporate social responsibility of islamic banks through their business processes and oriented outcomes? Int J Econ Financ Issues. 2015;5.

[13] Creswell JW. Research Design - Qualitative, Quantitative, and Mixed Methods Approach. Vol. 3. SAGE Publications; 2014. 273 p

[14] Neuman WL (William L. Social research methods : qualitative and quantitative approaches. 7th ed. Pearson; 2013. $598 \mathrm{p}$.

[15] Soejono. H, Abdurrahman H. Metode Penelitian: Suatu Pemikiran dan Penerapan. Cet.2. Rineke Cipta; 2005.

[16] Supardi. Metodologi penelitian ekonomi dan bisnis. Yogyakarta: UII Press; 2005. 354 p.

[17] Direktorat Perbankan Syariah Bank Indonesia. Kajian Aspek Perpajakan Pada Bank Syariah. Jakarta; 2004

[18] Fandy Tjiptono. Manajemen Jasa. Yogyakarta: Andi; 2007. 176 p.

[19] Fitzsimmons JA, Fitzsimmons MJ. Service management: operations, strategy, information technology. McGraw-Hill; 2011. $541 \mathrm{p}$.

[20] Grönroos C. Service management and marketing: managing the moments of truth in service competition. Lexington Books; 1990. $298 \mathrm{p}$.

[21] Gemmel P, Van Looy B, Van Dierdonck R. Service Management: an integrated approach. Pearson; 2013. 505 p.

[22] Lewis M, Algaoud LM. Islamic banking. Edward Elgar; 2001. 274

[23] Secretary-General of the OECD. International Value Added Tax/Goods and Services Tax Guidelines. Paris; 2017.

[24] Tait A. Value Added Tax. INTERNATIONAL MONETARY FUND; 1988.

[25] Hegazy W. Islamic Finance in Malaysia. 1999;215-24.

[26] Malaysian Institute of Accountants. TAX TREATMENT ON ISLAMIC FINANCE in Malaysia. Kuala Lumpur; 2012. 